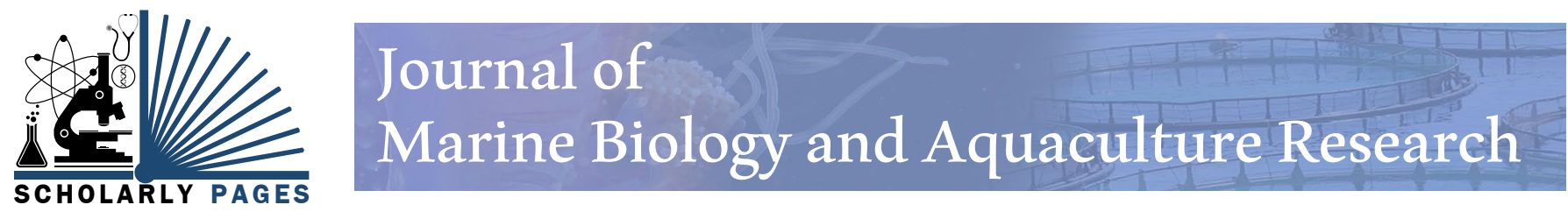

\title{
First Study about Aquaponic Systems in Albania
}

\author{
Rigers Bakiu ${ }^{1 *}$, Clirim Tafaj' and Jani Taci²
}

\author{
${ }^{1}$ Department of Aquaculture and Fisheries, Agricultural University of Tirana, Albania \\ ${ }^{2}$ N.S.P, Tirana, Albania
}

\begin{abstract}
There is an increasing demand from the domestic market of Albania and Eastern Europe countries for pesticide-free produce. Since aquaponic systems can produce fish and vegetables intensively throughout the year outdoors in suitable climates or in environmentally controlled greenhouses and land requirements are minimal, systems can be located near urban markets, thereby reducing transportation costs and providing fresh, high quality fish and plants for people living in Albania and other countries of similar climatic conditions. In order to evaluate the performance of the first aquaponics system in Albania and Balkans, we performed a comparison related to plants average growth between the traditional and aquaponics systems, respectively. We found that there were significant growth differences by height of peppers, eggplants, melons and cucumbers, when growing between aquaponic vs. traditional soil. However, this is one of the first efforts in Europe to provide information that can better inform research and education regarding aquaponics as it matures and possibly evolves into a mainstream form of agriculture.
\end{abstract}

Keywords

Aquaponics, Carassus auratus, Growth koi carp, Plant height

\section{Introduction}

Aquaponics is the mutually beneficial integration of hydroponics (e.g., soilless systems for crop production) and aquaculture (e.g., aquatic animal farming) to simultaneously produce plant and animal products. In an aquaponic system, aquatic animals excrete waste, bacteria convert the waste into nutrients, and plants remove the nutrients and improve water quality for the aquatic animals.

Aquaponics was influenced by work in the early 1970s by aquaculture researchers who experimented with raising fish in land-based tanks with continuously recycled water (e.g., Recirculating Aquaculture Systems or RAS). A major challenge for recirculating aquaculture was the accumulation of nitrogen compounds, a potentially toxic by-product of fish waste [1,2]. Investigators experimented with soilless plant systems as a means of treating fish waste and removing nitrogen compounds [3-6], which marked the beginnings of contemporary aquaponics. Engineers have since developed a variety of biofilters to treat fish waste that does not rely on plants [7]. The fact that aquaponic systems improved water quality and produced a second profit center, in the form of edible plants, is what distinguishes aquaponics from other forms of re- circulating aquaculture. The development of aquaponics was also influenced by the sustainable agriculture movement. The concept of farming in ways that mimic natural systems, known as permaculture, has been practiced for thousands of years, but was first codified by researchers in the mid-1970s in Australia [8].

It is touted as a form of sustainable agriculture, because it mimics natural systems, is water efficient, and has fewer environmental impacts than some forms of aquaculture [9]. Aquaponic systems exist at a variety of scales and for different uses: personal use or as a hobby, for community and economic development [10], as a teaching tool in science education [11], or as a means of increasing food production in urban settings, where opportunities for conventional agricultural production is

*Corresponding author: Rigers Bakiu, Department of Aquaculture and Fisheries, Agricultural University of Tirana, Tirane, Albania, E-mail: rigers.bakiu@ubt.edu.al

Received: April 14, 2017; Accepted: June 30, 2017; Published online: July 03, 2017

Citation: Bakiu R, Tafaj C, Taci J (2017) First Study about Aquaponic Systems in Albania. J Mar Biol Aquaculture Res 1(1):1-7

Copyright: (c) 2017 Bakiu R, et al. This is an open-access article distributed under the terms of the Creative Commons Attribution License, which permits unrestricted use, distribution, and reproduction in any medium, provided the original author and source are credited. 


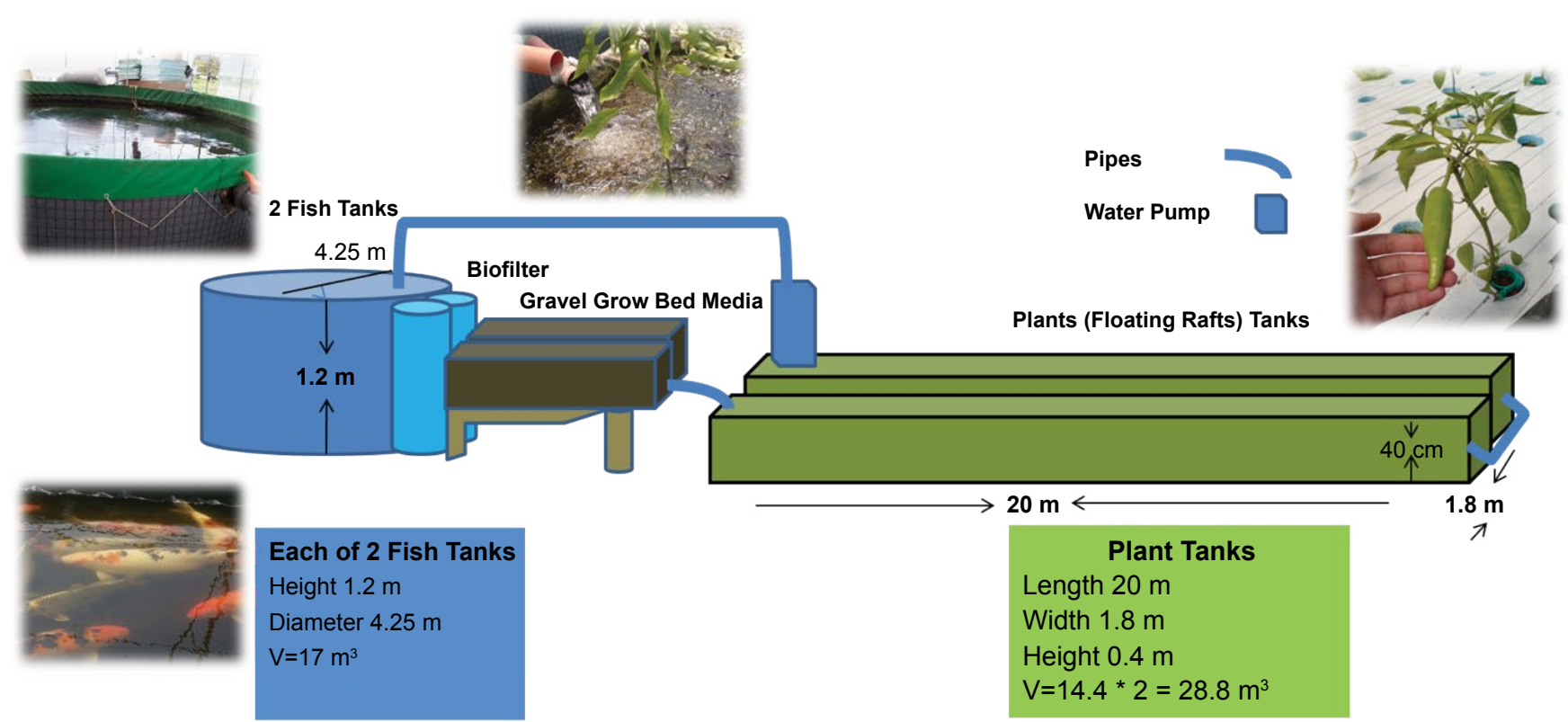

Figure 1: Schematic representation of the aquaponics system, where all the experiments were performed at the same time with the traditional soil experiments.

limited due to environmental contamination and space limitations [12].

However there are only a scarce number of scientific publications regarding aquaponics [13-17]. Based on the data reported from the scientific paper entitled "An International Survey of Aquaponics Practitioners", where are reported the results of the survey performed by Love and colleagues [13], eighty-three percent of aquaponic systems $(n=657)$ were self-designed by the respondent. The remaining $17 \%$ of respondents $(n=135)$ reported hiring a consultant to design the aquaponic system and/ or purchasing an aquaponic kit.

Respondents used a variety of methods for raising crops, but the most common were containers filled with media (i.e., media beds), used by $86 \%$ of respondents. Forty-six percent of respondents grew plants on floating rafts, 19\% used a Nutrient Film Technique (NFT), 17\% use vertical growing towers, $2 \%$ used wicking beds, and $2 \%$ used traditional irrigation or Dutch buckets. In this research paper [13], respondents often combined multiple growing methods, where the most common combination of methods used by respondents was media beds and rafts (35\% of total). Like this group of practitioners, the owner (Engr. Jani Taci) of the first aquaponics system in Albania designed and built this integrated aquaculture system by himself in 2012. In this aquaponics system, the most used fish species are represented by Koi carp and goldfish (Carassus auratus), which is known to be the most used in aquaponics systems. Both species produce high levels of ammonia, which is good for maintaining nutrient levels for the aquaponic process. Both fish are also very resilient to changes in $\mathrm{pH}$, pollutants, and tem- perature [18].

Published comparisons of crop production methods are rare, although one study found lettuce grew best by the following order of methods: media beds $>$ floating raft > nutrient film technique [19], which aligns with the frequency of crop production methods reported by respondents in this study [13]. In order to try to find the best approach for raising crops in aquaponic systems in Albania, we followed the investigation approach used by Yamamoto and Brock [20] and we found that there were significant growth differences by height of peppers, eggplants, melons and cucumbers, when growing between aquaponic vs. traditional soil. However, further studies in length and repetition is required to confirm whether aquaponics is less efficient than the traditional soil method for crops like those previously mentioned.

\section{Materials and Methods}

\section{Fish and Plants}

All the experiments were performed in the aquaponics system, which was built as a hobby by Eng. Jani Taci (Civil Engineer) in Maminas Village, near Tirana, the capital city of Albania. In the Figure 1, it is shown the representative scheme of the aquaponics system with the real dimensions of each component (Recirculating Aquaculture System-RAS and Hydroponic Subsystem, respectively). The gold fish (C. auratus) and Koi carp ( $C$. carpio) were bought from the Hatchery of Tapiza (property of Agricultural University of Tirana) and they (fingerlings with an average weight of $30 \mathrm{~g}$ ) were transferred in the tanks shown in Figure 1. In order to have a sufficient flux $(2500 \mathrm{l} / \mathrm{h})$ of water in the aquaponics system, a 
powerful pond water pump of $620 \mathrm{~W}$ was installed and immerged in the plants tank. Plant seedlings of peppers, eggplants, melons and cucumbers were taken from the nursery area located in the greenhouse soil, where it is located also the aquaponics system. An average of 15 seedlings was planted in the soil for each of the considered crops. 15 seedlings of peppers, cucumbers and eggplants were inserted in the plastic glasses and filled with perlite. Then they were inserted in the holes of the polystyrene sheets floating on the water. Other 15 seedling of melons were planted in the gravel media of the aquaponics system shown in Figure 1.

\section{Height measurements}

Each plant growth height was measured every three days with the exception of Day 11, when it was observed a reduced growth rate of pants height. An average height was taken for each considered plant in the study (peppers, eggplants, melons and cucumbers) in centimeters $(\mathrm{cm})$. In addition, qualitative observations were also taken for each plant. In the aquaponics system, peppers, eggplants and cucumbers were grown on floating rafts, while melons were grown in gravel growing media.

\section{Water quality parameters monitoring}

In order to take the water quality parameters under control, the $\mathrm{pH}$ were measured using Adwa kft AD12 (CE, Made in Romania) $\mathrm{pH}$ meter and a digital thermometer (HM Digital EC-3) was used to measure temperature in Celsius.

\section{Statistical tests}

OriginPro 2016 (Origin Lab, Northhampton, MA) software was used to perform the two samples T-tests in order to ensure significance of data $p=<0.05$, where the comparison was performed between height mean values of peppers, eggplants, melons and cucumbers in aquaponics vs. traditional soil systems.

\section{Results}

In order to evaluate the performance of the first aquaponics system in Albania and Balkans, we performed a

Table 1: Results of two sample T-tests, where the peppers height mean values of aquaponics were compared to those of soil system and the differences were statistically evaluated for $p<0.05$, after the two sample test for variance was performed by using OriginPro 2016 (OriginLab, Northhampton, MA).

\begin{tabular}{|c|c|c|c|c|c|c|c|}
\hline Time & $\begin{array}{l}\text { Traditional } \\
\text { system mean }\end{array}$ & $\begin{array}{l}\text { Traditional } \\
\text { system } \\
\text { standard } \\
\text { deviation }\end{array}$ & $\begin{array}{l}\text { Aquaponic } \\
\text { system mean }\end{array}$ & $\begin{array}{l}\text { Aquaponic } \\
\text { system } \\
\text { standard } \\
\text { deviation }\end{array}$ & Prob $>|t|$ & $\begin{array}{l}\text { Two sample test for } \\
\text { variance }\end{array}$ & Prob $>F$ \\
\hline Day 0 & 21.81 & 2.66 & 22.7 & 2.27 & 0.38 & Equal variances & 0.6 \\
\hline Day 4 & 22.67 & 2.58 & 23.9 & 2.43 & 0.21 & Equal variances & 0.85 \\
\hline Day 7 & 25.25 & 2.67 & 24.8 & 2.56 & 0.62 & Equal variances & 0.91 \\
\hline Day 11 & 27.88 & 2.94 & 26.3 & 2.96 & 0.18 & Equal variances & 0.95 \\
\hline Day 18 & 35 & 3.81 & 29.3 & 3.17 & $2.51 \mathrm{E}-04$ & Equal variances & 0.54 \\
\hline Day 25 & 43.13 & 5.62 & 32.8 & 3.65 & 7.65E-06 & Equal variances & 0.15 \\
\hline Day 32 & 54.75 & 7.07 & 36.4 & 4.17 & $1.83 \mathrm{E}-08$ & Equal variances & 0.08 \\
\hline Day 39 & 62.81 & 8.15 & 38.2 & 3.71 & $3.21 \mathrm{E}-10$ & Different variances & 0.01 \\
\hline Day 46 & 70.44 & 8.99 & 41.5 & 4.93 & $1.92 \mathrm{E}-10$ & Equal variances & 0.05 \\
\hline
\end{tabular}

Prob $>|t|$ and Prob $>\mathrm{F}$ indicate if the $\mathrm{p}$-value was less than 0.05 in the two sample $\mathrm{t}$-tests and two sample tests for variance, respectively.

Table 2: Results of two sample T-tests, where the eggplants height mean values of aquaponics were compared to those of soil system and the differences were statistically evaluated for $p<0.05$, after the two sample test for variance was performed by using OriginPro 2016 (OriginLab, Northhampton, MA).

\begin{tabular}{|l|l|l|l|l|l|l|l|}
\hline Time & $\begin{array}{l}\text { Traditional } \\
\text { system mean }\end{array}$ & $\begin{array}{l}\text { Traditional system } \\
\text { standard deviation }\end{array}$ & $\begin{array}{l}\text { Aquaponic } \\
\text { system mean }\end{array}$ & $\begin{array}{l}\text { Aquaponic system } \\
\text { standard deviation }\end{array}$ & Prob $\boldsymbol{|}|\mathbf{t}|$ & $\begin{array}{l}\text { Two sample test } \\
\text { for variance }\end{array}$ & Prob $>$ F \\
\hline Day 0 & 4.15 & 0.8 & 5.21 & 1.42 & 0.03 & Equal variances & 0.05 \\
\hline Day 4 & 4.69 & 0.85 & 5.64 & 1.39 & 0.04 & Equal variances & 0.1 \\
\hline Day 7 & 6 & 1.08 & 5.21 & 1.42 & 0.12 & Equal variances & 0.35 \\
\hline Day 11 & 7.23 & 1.17 & 8 & 1.36 & 0.13 & Equal variances & 0.6 \\
\hline Day 18 & 10.77 & 1.59 & 9.64 & 1.69 & 0.09 & Equal variances & 0.83 \\
\hline Day 25 & 16.85 & 4.51 & 12.36 & 1.91 & $4.30 \mathrm{E}-03$ & Different variances & $4.23 \mathrm{E}-03$ \\
\hline Day 32 & 32.15 & 9.61 & 17 & 3.19 & $8.15 \mathrm{E}-05$ & Different variances & $3.58 \mathrm{E}-04$ \\
\hline Day 39 & 44.08 & 12.2 & 18.93 & 3.93 & $4.73 \mathrm{E}-06$ & Different variances & $2.63 \mathrm{E}-04$ \\
\hline Day 46 & 61.46 & 12.36 & 21.36 & 5.39 & $8.66 \mathrm{E}-09$ & Different variances & $5.62 \mathrm{E}-03$ \\
\hline
\end{tabular}

Prob $>|t|$ and Prob $>\mathrm{F}$ indicate if the $\mathrm{p}$-value was less than 0.05 in the two sample $\mathrm{t}$-tests and two sample tests for variance, respectively. 
comparison related to plants average growth (height) between the traditional and aquaponics systems, respectively.

One of the two aquaponics experiment tanks contained 172 individuals of gold fish and the other one contained 63 individuals of Koi carp, where the average weight of gold fish and Koi carp were 0.8 and $2.5 \mathrm{~kg}$, respectively. Thus, the average fish density of each tank with an average volume of $17 \mathrm{~m}^{3}$ was 8 and $9 \mathrm{~kg} / \mathrm{m}^{3}$ for gold fish and Koi carp, respectively.

In the Table 1, Table 2, Table 3 and Table 4 are presented the height means and the relative standard deviations of peppers, eggplants, cucumbers and melons in the comparisons between the traditional soil and aquaponics systems for each of the experiments day. Two Samples T-tests were performed in order to evaluate if the difference of height means for each of the plants was statistically significant. In these tables are reported the $\mathrm{p}$-values (or Prob $>|\mathrm{t}|$ ) and it is shown the Two Sample Test for Variance result for each of the performed Two Samples T-tests and the respective p-value (Prob $>$ F).

In the Figure 2, Figure 3, Figure 4 and Figure 5 are shown the graphical representations of the peppers, egg plants, cucumbers and melons growth comparisons be- tween traditional soil and aquaponics systems. In the aquaponics system, peppers, eggplants and cucumbers

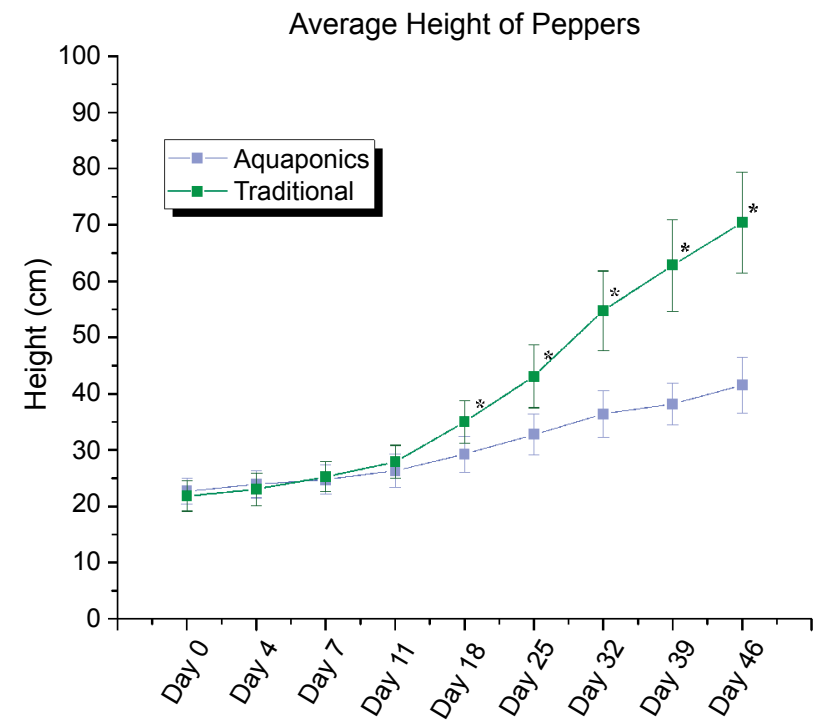

Figure 2: Graphical representation of the comparison between peppers average height values from aquaponics and traditional soil systems for each analyzed day.

"indicate the presence of statistically significant differences between the two production systems peppers height mean values $(p<0.05)$.

Table 3: Results of two sample T-tests, where the cucumbers height mean values of aquaponics were compared to those of soil system and the differences were statistically evaluated for $p<0.05$, after the two sample test for variance was performed by using OriginPro 2016 (OriginLab, Northhampton, MA).

\begin{tabular}{|l|l|l|l|l|l|l|l|}
\hline Time & $\begin{array}{l}\text { Traditional } \\
\text { system mean }\end{array}$ & $\begin{array}{l}\text { Traditional system } \\
\text { standard deviation }\end{array}$ & $\begin{array}{l}\text { Aquaponic } \\
\text { system mean }\end{array}$ & $\begin{array}{l}\text { Aquaponic system } \\
\text { standard deviation }\end{array}$ & Prob $>$ |t| & $\begin{array}{l}\text { Two sample test } \\
\text { for variance }\end{array}$ & Prob $\mathbf{>} \mathbf{F}$ \\
\hline Day 0 & 7.5 & 1.58 & 3.6 & 0.97 & $3.03 \mathrm{E}-06$ & Equal variances & 0.16 \\
\hline Day 4 & 8.5 & 1.65 & 5.3 & 1.25 & $1.19 \mathrm{E}-04$ & Equal variances & 0.42 \\
\hline Day 11 & 15.7 & 1.83 & 10 & 1.76 & $1.30 \mathrm{E}-06$ & Equal variances & 0.92 \\
\hline Day 18 & 24.5 & 5.28 & 21.4 & 3.81 & 0.15 & Equal variances & 0.34 \\
\hline Day 25 & 41.8 & 9.73 & 38.2 & 5.25 & 0.32 & Equal variances & 0.08 \\
\hline Day 32 & 60 & 14.79 & 48.6 & 6.48 & 0.04 & Different variances & 0.02 \\
\hline Day 39 & 79 & 19.63 & 51.1 & 5.72 & $1.36 \mathrm{E}-03$ & Different variances & $1.11 \mathrm{E}-03$ \\
\hline
\end{tabular}

Prob $>|t|$ and Prob $>F$ indicate if the $p$-value was less than 0.05 in the two sample $t$-tests and two sample tests for variance, respectively.

Table 4: Results of two sample T-tests, where the melons height mean values of aquaponics were compared to those of soil system and the differences were statistically evaluated for $p<0.05$, after the two sample test for variance was performed by using OriginPro 2016 (OriginLab, Northhampton, MA).

\begin{tabular}{|l|l|l|l|l|l|l|l|}
\hline Time & $\begin{array}{l}\text { Traditional } \\
\text { system mean }\end{array}$ & $\begin{array}{l}\text { Traditional system } \\
\text { standard deviation }\end{array}$ & $\begin{array}{l}\text { Aquaponic } \\
\text { system mean }\end{array}$ & $\begin{array}{l}\text { Aquaponic system } \\
\text { standard deviation }\end{array}$ & Prob > |t| & $\begin{array}{l}\text { Two sample test } \\
\text { for variance }\end{array}$ & Prob $>$ F \\
\hline Day 0 & 5.81 & 1.22 & 5.4 & 1.92 & 0.48 & Equal variances & 0.09 \\
\hline Day 4 & 7 & 1.1 & 5.67 & 2.06 & 0.04 & Different variances & 0.02 \\
\hline Day 7 & 8.75 & 1.69 & 5.4 & 1.92 & $1.62 \mathrm{E}-05$ & Equal variances & 0.63 \\
\hline Day 11 & 13.69 & 2.82 & 6.6 & 2.1 & $1.05 \mathrm{E}-08$ & Equal variances & 0.27 \\
\hline Day 18 & 42.31 & 5.2 & 9.87 & 3.04 & $4.27 \mathrm{E}-19$ & Equal variances & 0.05 \\
\hline Day 25 & 94.81 & 16.03 & 16.6 & 5.14 & $2.81 \mathrm{E}-13$ & Different variances & $1.15 \mathrm{E}-04$ \\
\hline Day 32 & 157.56 & 20 & 26.8 & 8.55 & $1.68 \mathrm{E}-16$ & Different variances & $2.81 \mathrm{E}-13$ \\
\hline Day 39 & 205 & 11.55 & 38.13 & 11.87 & $8.01 \mathrm{E}-27$ & Equal variances & 0.91 \\
\hline Day 46 & 221.25 & 13.1 & 51.4 & 15.26 & $1.14 \mathrm{E}-24$ & Equal variances & 0.56 \\
\hline
\end{tabular}

Prob $>|t|$ and Prob $>F$ indicate if the $p$-value was less than 0.05 in the two sample $t$-tests and two sample tests for variance, respectively. 


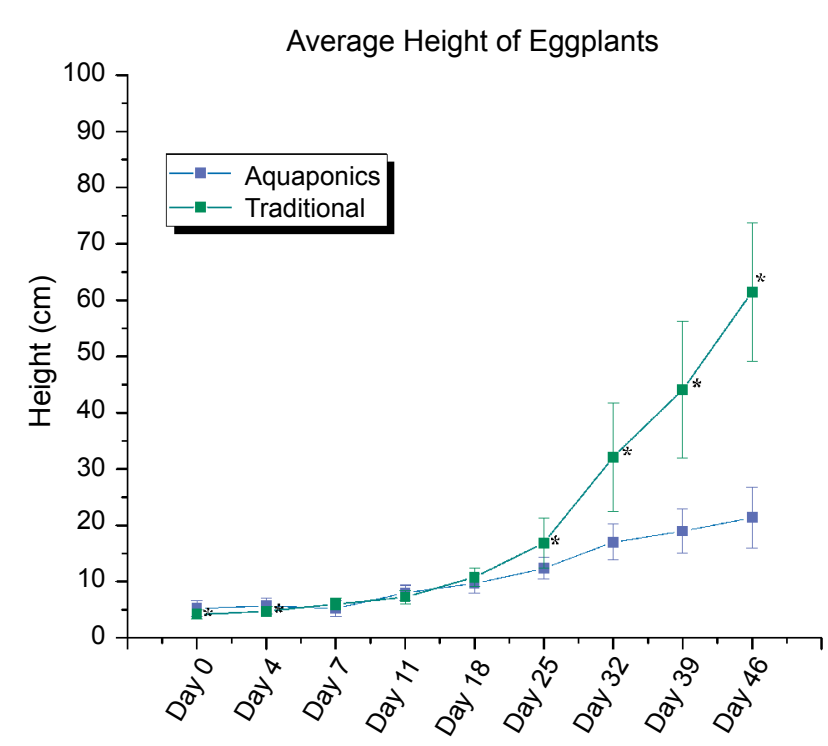

Figure 3: Graphical representation of the comparison between eggplants average height values from aquaponics and traditional soil systems for each analyzed day.

*indicate the presence of statistically significant differences between the two production systems eggplants height mean values $(p<0.05)$.

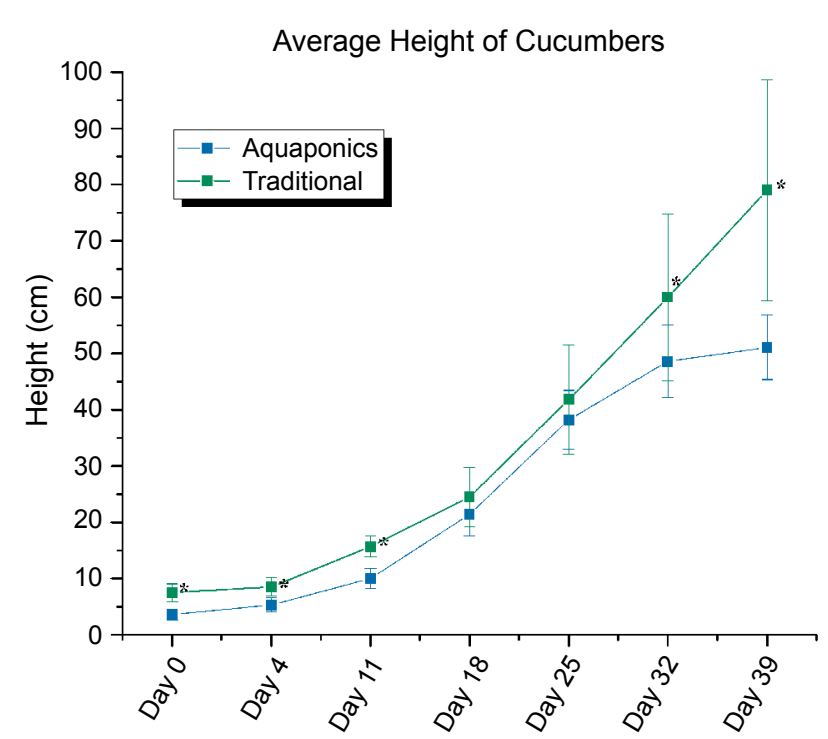

Figure 4: Graphical representation of the comparison between cucumbers average height values from aquaponics and traditional soil systems for each analyzed day.

*indicate the presence of statistically significant differences between the two production systems cucumbers height mean values $(p<0.05)$.

were grown in the floating rafts, while the melons were grown in the gravel growing bed. As it is shown in Table 1 and Figure 2, the average height values of peppers in the aquaponics system were higher than those of the peppers of the traditional soil system till the day 4 . From the day 7 till the end of experiments, the height values of peppers in the aquaponics system were lower than those

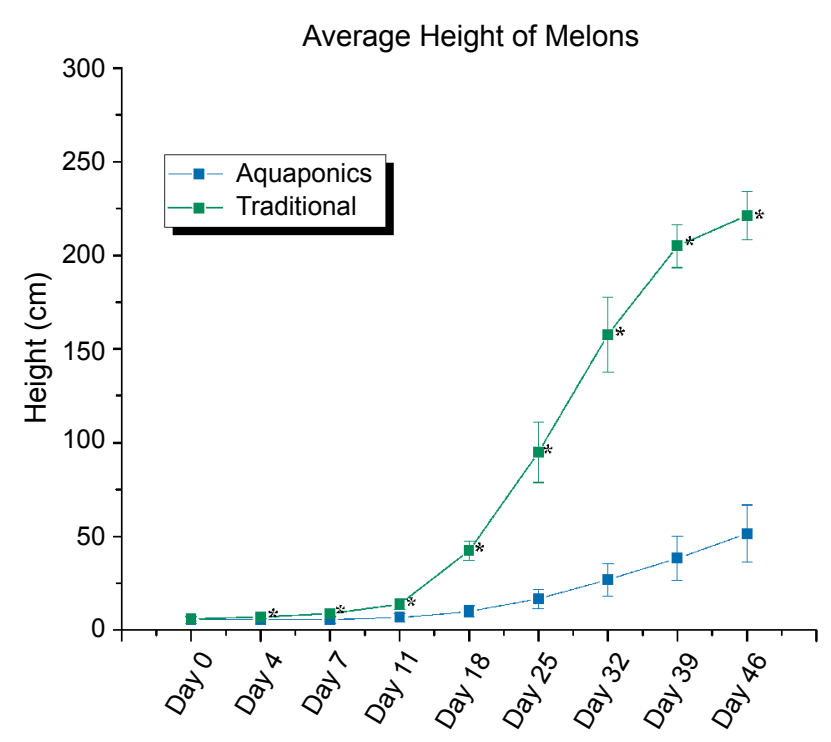

Figure 5: Graphical representation of the comparison between melons average height values from aquaponics and traditional soil systems for each analyzed day.

*indicate the presence of statistically significant differences between the two production systems melons height mean values $(p<0.05)$.

of peppers growing in the soil. In fact the average height differences between the two considered production systems were statistically significant for p-values less than 0.05 , only after 18 days. Furthermore, the variances of each day height means comparison were not different except those of the day 39, which difference was statistically significant for a p-value less than 0.05 .

In Table 2 and Figure 3 it is shown that similarly to the experiments with the peppers, the eggplants in the aquaponics system were higher than those of the traditional soil system eggplants till the day 4 . Just after the 7 -th day the height mean values of eggplants in aquaponics system were lower than those of eggplants in the soil. These differences became statistically significant for a p-value less than 0.05 , only after 25 days. As it is shown in Table 2, the variances difference became statistically significant at the day 25 height mean values comparisons. From the observations in the Table 3 and Figure 4, it is interesting to note that even just from the experiments start the differences of the cucumbers mean height values were statistically significant, the statistical significance disappeared after 18 days and these differences were again statistically significant for a $p$-values less than 0.05 , at the end of the performed experiments with cucumbers. From the two sample tests for variance emerged that the variances differences were statistically significant only after 32 days. As, it is shown in the Table 4 and Figure 5, the average height values of melons in the gravel were lower than those of the melons in the soil just after 4 days and all the differences were statistically sig- 
nificant for a p-value less than 0.05 . Only at day 4,25 and 32 , the variances differences were statistically significant for p-values less than 0.05 .

\section{Discussion}

Environmental control, water quality and the use of soilless cultivation practices in aquaponics allows pesticide free production. In fact, pesticides cannot be used because of damage to the fish. There is an increasing demand from the domestic market of Albania for pesticide-free produce. Since aquaponic systems can produce fish and vegetables intensively throughout the year outdoors in suitable climates or in environmentally controlled greenhouses and land requirements are minimal, systems can be located near urban markets, thereby reducing transportation costs and providing fresh, high quality fish and plants. Furthermore, future increases in atmospheric carbon dioxide levels and temperature are expected to promote a lengthening of the crop growing season, resulting in increased crop yields and a general northward shift of crops in Europe. The degree, to which these potential future increases in crop yield are realized, however will be strongly dependent upon the availability of water.

In southern Europe, increased temperatures and decreased precipitation will result in a general decrease in water availability, exacerbated by an increase in the frequency and severity of droughts. Albania is one of the most vulnerable in the southeastern Europe to changing climate trends. Changing weather patterns have already been observed over the last 15 years with increasing temperatures, decreasing precipitation, and more frequent extreme events like floods and droughts. While these changes in climate and their resulting effects on agriculture will have an impact on the global population at large, it is the rural populations who are most vulnerable. The pollution of the environment, which is caused by destruction (conflict/bombing/military actions in Balkan region, i.e. on territory of former Yugoslavia) of industrial installations and urban infrastructure as well as military and other waste, including mines and unexploded ordinances, has impacted soils, watercourses and has rendered difficult or impossible the use of large areas of arable land.

All these reason pushed us to perform a series of experiments, where it could be possible to evaluate the performance and/or efficiency of the aquaponics system in comparison to the traditional soil system. As it is indicated by the results presented in tables (Table 1, Table 2, Table 3 and Table 4) and figures (Figure 2, Figure 3, Figure 4 and Figure 5) differently from the Yamamoto and Brock [20] results, which showed that there were no significant growth differences by height of peas, tomatoes, and beans, when growing between aquaponic vs. traditional soil for a $\mathrm{p}<0.05$, generally in our study there a statistically significant difference between the growth of peppers, eggplants and cucumbers growing between aquaponics vs. traditional soil for a p-values less than 0.05 . These differences are even bigger when the comparison is between the melons growing in gravel growing beds of the aquaponics system vs. soil. Thus melons are not recommended to grow in aquaponics systems even we try for the first time to grow it in gravel growing media of aquaponics system.

Anyway, our study plants were different from those considered in the study performed by Yamamoto and Brock [20] and there are no other similar published papers. However, it very important to note that by observing the shape of the curves and the relative growth rate of cucumbers growing in aquaponics and soil (Figure 4), there is high similarity between these rates till the day 25 , although the height mean values are significantly different for $\mathrm{p}<0.05$. Probably, cucumbers are the best crop to produce by using aquaponics systems in Albania, Balkans and nearby regions of similar climatic conditions. Our findings indicate that experimentation in crop production is active and ongoing; almost research, optimization, and communication of the best crop production methods are needed among the aquaponics community of Europe. These findings can help inform aquaponics practices and serve as a baseline for exploring future trends in aquaponics. In addition to more research, outreach and communication efforts are needed to translate findings to individuals engaged in aquaponics, and to elicit feedback about future directions of study.

\section{Acknowledgments}

This paper is Clirim Tafaj's Master thesis in Aquaculture and Fisheries Management (Agricultural University of Tirana, Department of Aquaculture and Fisheries).

\section{References}

1. Bohl M (1977) Some initial aquaculture experiments in recirculating water systems. Aquaculture 11: 323-328.

2. Collins M, Gratzek J, Shotts Jr E, et al. (1975) Nitrification in an Aquatic Recirculating System. Journal of the Fisheries Research Board of Canada 32: 2025-2031.

3. Naegel LCA (1977) Combined production of fish and plants in recirculating water. Aquaculture 10: 17-24.

4. Sneed K, Allen K, Ellis J (1975) Fish farming and hydroponics. Aquaculture Fish Farming 2: 18-20.

5. Lewis WM, Yopp JH, Schramm JHL (1978) Use of hydroponics to maintain quality of recirculated water in a fish culture system. Transactions of The American Fisheries Society 107: 92-99.

6. Sutton RJ, Lewis WM (1982) Further observations on a fish production system that incorporates hydroponically grown plants. Programing Fish-Culturist 44: 55-59. 
7. Timmons M, Ebeling J (2010) Recreation Aquaculture Ithica. Cayuga Aqua Ventures, Nutrition, NY.

8. Mollison B, Holmgren D (1981) Permaculture One: A Perennial Agricultural System for Human Settlements. International Tree Crop Institute, USA.

9. Blidariu F, Grozea A (2011) Increasing the Economical Efficiency and Sustainability of Indoor Fish Farming by Means of Aquaponics-Review. Scientific Papers: Animal Science and Biotechnologies 44: 1-8.

10. Goodman E (2011) Aquaponics: community and economic development. Massachusetts Institute of Technology, 97100.

11. Wardlow G, Johnson D, Mueller C (2002) Enhancing student interest in the agricultural sciences through aquaponics. J Nat Resour Life Sci Educ 31: 55-58.

12. Metcalf S, Widener M (2011) Growing Buffalo's capacity for local food: A systems framework for sustainable agriculture. Applied Geography 31: 1242-1251.

13. Love DC, Fry JP, Genello L, et al. (2014) An International Survey of Aquaponics Practitioners.

14. Zou Y, Hu Z, Zhang J (2016) Effects of pH on nitrogen transformations in media-based aquaponics. Bioresources Technology 210: 81-87.
15. Munguia-Fragozo $P$, Alatorre-Jacome O, Rico-Garcia E, et al. (2015) Perspective for Aquaponic Systems: "Omic" Technologies for Microbial Community Analysis. BioMed Research International 2015: 480386.

16. Hu Z, Lee JW, Chandran K, et al. (2015) Effect of plant species on nitrogen recovery in aquaponics. Bioresource Technology 188: 92-98.

17. Tokuyama T, Mine A, Kamiyama K (2004) Nitrosomonas communis strain YNSRA, an ammonia-oxidizing bacterium, isolated from the reed rhizoplane in an aquaponics plant. $\mathrm{J}$ Biosci Bioeng 98: 309-312.

18. Johanson EK (2013) Aquaponics and Hydroponics on Budget. Technical Directions 69: 21-23.

19. Lennard WA, Leonard BV (2006) A Comparison of Three Different Hydroponic Sub-systems (gravel bed, floating and nutrient film technique) in an Aquaponic Test System. Aquac Int 14: 539-550.

20. Yamamoto J, Brock A (2014) A Comparison of the Effectiveness of Aquaponic Gardening to Traditional Gardening Growth Method. 